\title{
Historical Fiction as a Mixture of History and Romance: Towards the Genre Definition of the Historical Novel
}

\section{Ladislav Nagy}

This article focuses on Walter Scott's Waverley and its classification as the founding text of the historical novel by Georg Lukács. The author attempts to show that Lukács takes Scott too much at his word and posits Waverley in the tradition of the English historical novel as it developed from Defoe and Fielding, while neglecting the close ties that Waverley has with marginalized genres such as romance. The author also argues that rather than being an expression of class consciousness, Waverley is an attempt to justify a certain change in political attitude, from radicalism to conservatism.

\section{Keywords}

Historical fiction; Tudory; novel; Walter Scott; György Lukács

Even a cursory look at contemporary British fiction - or fiction written worldwide for that matter - will reveal two phenomena: the dominance of the novel as a genre; and a number of novels dealing with or inspired by history. "The sudden overflowing of the historical novel in Britain" after WWII is something that has been observed, analysed or otherwise commented upon by many writers, critics and scholars. It has been also noted that the "renaissance of the historical novel has coincided with a complex self-consciousness about the writing of history itself" (Byatt 9). David Leon Higdon, for instance, sees the turn to history as the "definitive element in British fiction in the last three decades", while Suzanne Keen and Linda Duguid agree that historical fiction has become "respectable, even intellectual" (de Groot 2).

The genre spectrum of historical fiction, however, is wide and the boundaries vague, spanning detective stories, romances, horror stories, thrillers, fantasy, mystery and books for children. "Indeed, the intergeneric hybridity and flexibility of historical fiction have long been one of its defining characteristics", says Jerome de Groot, adding that "a historical novel might consider the articulation of nationhood via the past, highlight the subjectivism of narratives of History, underline the importance of the realist mode of writing to notions of 
authenticity, question writing itself, and attack historiographical convention" (2). Despite its genre legacy, however, historical fiction has been raised, recently, to an altogether different level of seriousness. What once conjured up "cloaks, daggers, crinolined ladies, ripped bodices, sailing ships in bloody battles" and was dismissed as "escapism" (Byatt 9), is suddenly hailed as endowed with "literary energy and real inventiveness" and considered a highly intellectual endeavour: "Writing historical novels is no longer something to be considered vulgar, the preserve of romance writers, or guaranteed to tie one to a particular type of genre" (98).

Historical fiction has established itself as a serious intellectual endeavour since its overall theme seems to have something to contribute to the current discussions about the nature of history and the character of story-telling. Secondly, the historical element and the attitude to the past was seen by some - David Leon Higdon, among others - as a defining feature of contemporary fiction, differentiating it from modernism. Many critics today subscribe to Hayden White's statement that while the modernists strived to escape the "burden of history", the post-war writers engage with memory, tradition and history, the three main representation of the past. Linda Hutcheon, in her seminal study A Poetics of Postmodernism, celebrates the new historical novel as a form that restores history at the very core of the novelistic practice, in which novelists, by being aware of their ontological and epistemological status, come forth with the question whether we can indeed know the past and represent it in a coherent narrative. Today's theory refuses both great narratives and the reductionist historical strategy that enabled and supported the idea of progress. Historians and theoreticians of narrative, Hayden Whiter, Paul Veyne, E. J. Hobsbawm and others, have drawn attention to the fact that both tradition and history were constructed, i.e., something that does not exist in itself and beyond society but is, rather, continually created in interpretations. As such, both tradition and history are products of language, which is an insight that has opened up a new field in the study of intertextuality. This, of course, proved to be an inspiration for novelists: if historiographers use the same techniques, methods and strategies as novelists, is there then indeed a difference between the two? And, consequently, can fiction come with the same claims as history-writing.

The question of history's claim to truth has been debated over the last few decades with much intensity. Among those who have made great efforts to elucidate the question and to provide satisfactory answers, Roger Chartier, mainly in his L'histoire ou le récit veridique and Au bord de la falaise. L'histoire 
entre certitudes and inquiétude, suggests replacing the objectivity of historical knowledge by its adequacy, which, however, is always considered in relation to the questions asked, methods chosen and sources studied - which is hardly helpful to provide answers to disturbing questions raised by the work of Hayden White. Paul Ricoeur, while not going as far as Hayden White, nevertheless emphasizes the importance of narrative when he claims, following Cassirer, that it is through narrative, which necessarily uses a plot, that our shapeless, vague and silent experience is prefigured.

The aim of this essay is not to argue that all historical fiction of the last decades examines the troubled relationship between historical truth and fictitious narrative, for this is clearly not the case. Rather, I want to argue that historical fiction has always drawn some of its appeal and drive from the blurred divide between fact and imagination or, to be more precise, from the permeability and contested status of this frontier. This tension, I want to argue, is precisely what gives the best representatives of historical fiction their literary power and what makes them classics. I do not think it necessary to discuss all historical fiction - as Linda Hutcheon does - as historiographic metafiction. Rather, I think, it may be worthwhile to pay close attention to the genre characteristics of each particular work and the way its authors negotiate the relationship of the work towards the literary canon and justifies their claim to truth by differentiating themselves from others. This is all the more pressing since the theoretical framework of the past decades, mentioned briefly above, proved to be a liberating influence on historical fiction. Hayden White, Paul Veyne and Michel Foucault have cast a shadow of doubt on the "objectivity" of history writing and its claim to truth. In criticism, the "historical turn" has been eloquently described by Linda Hutcheon (emphasis on historiographic metafiction), Brian McHale (postmodern ontologies), Charles Jencks (postmodern classicism), Fredric Jameson (postmodern pastiche), more recently by Mariadele Boccardi (the historical novel and the national identity), Amy J. Elias (the postmodern consciousness as a post-traumatic consciousness that redefines positivist or "stadialist history as the historical sublime" (Elias xviii)) and many others.

It is clear indeed that historical fiction has attained a new sense of urgency. It is far from being seen as mere entertainment, it is something more: a statement about our past and the way it influences our present, an effort to unravel something about the past that we have not yet been able to see, or, even, an opportunity to give us a different past and to grasp one's identity in a completely different way. However, when discussing historical fiction 
and its contribution to the history/fiction debate, one should not lose sight of the legacy and origins of historical fiction which is rather more complex than might seem.

Perhaps all too easily all historical fiction is - just because it is written in the form of prose - categorized as "historical novel" and interpreted along the lines set by György Lukács who sees the historical novel as a genre in its own right, or, rather, as a genre par excellence, with Walter Scott as its founding father. What Lukács has to say about Scott, however, is so much determined by his Hegelian legacy that a question arises whether his theory of the historical novel is not proved wrong precisely by the kind of literature he advocates. The very effort to examine "the intersection of the historical spirit and the great genres of literature which portray the totality of history" (9) would certainly be seen as dubious in today's context. Also Lukács's dictum that "the appeal to national independence and national character is necessarily connected with a re-awakening of national history, with memories of the past, of past greatness, of moments of national dishonour, whether this results in a progressive or reactionary ideology" (23) is understandable only insofar one takes for granted a particular intellectual framework, namely that of Hegelianism and Marxism.

Lukács takes Waverley as the founding text of the historical novel and boldly states that "the most important thing here is the increasing historical awareness of the decisive role played in human progress by the struggle of classes in history" (26). Whether the struggle of classes in history played any role in human progress, positive or negative, is an interesting question indeed but certainly not the one asked by Scott in Waverley. A few pages later Lukács comes up with another bold claim: "Scott's historical novel is the direct continuation of the great social novel of the 18th century", adding that "Scott endeavours to portray the struggles and antagonisms of history by means of characters who, in their psychology and destiny, always represent social trends and historical forces" (30-33).

These statements beg questions in a number of ways. First, to say that Scott builds upon the great social novel of the 18 th century remains to be proved. It is indeed Scott's claim in the preface that his book is much different from romances and is close to the novel, namely in that it is realistic, but as far as other genre characteristics are concerned, Waverley is actually much closer to earlier romances. The character of the eponymous hero, for instance, is rather distant from the likes of Tom Jones or Moll Flanders and shows very little development throughout the novel - apart from the fact that he 
renounces his romantic ideals as folly and takes a conservative stance. The same holds true for the second statement: if Waverley represents a social trend, then it is the massive wave of conservatism that swept across Europe after the fall of Napoleon and was represented in Britain by the adoption of a conservative outlook by the leading first generation Romantics which was seen, consequently, as a huge sell-out by the second generation, namely by writers such as Hazlitt, Hunt and Shelley.

The Hegelian concept of the spirit seems to be applied here by Lukács. An individual is identified with his class and, subsequently, the story of this "class" is read along the same lines as the stories of individual development, which we find in the novels of Defoe, Fielding, Richardson and Sterne. Thus, for Lukács, the historical novel becomes the novel par excellence. While in the traditional perspective of the rise of the novel - as described by Ian Watt in his 1949 book - the genre form of the novel is closely related to the rise of individual consciousness, business ethos of the late 18th century and individualism, in Lukács's framework it becomes an expression of the Zeitgeist and a certain class ("bourgeois") consciousness - this, I think, is the main reason why Scott is an absolutely essential author for Lukács and why Waverley serves as a (highly politicized) connection between the present and the past: "What matters therefore in the historical novel is not the retelling of great historical events, but the poetic awakening of the people who figured in those events. What matters is that we should re-experience the social and human motives which led men to think, feel and act just as they did in historical reality" (27).

Lukács considers Scott's Waverley to be the very first historical novel and he, rather strictly, differentiates it from the historicizing romance of the pre-Romantic period, such as the Gothic novel which can indeed be seen, in certain light, as the "fetishisation of European history" (de Groot 14). Lukács, however, seems to take Scott too much at face value since the reasons to classify Waverley as the founding text of an independent genre are two: first, Scott says explicitly that the story is narrated with the distance of sixty years, i.e., sufficiently short to understand the period but, at the same time, remote enough to exceed the horizon of individual memory; second, Scott explicitly treats the topic of history and the relationship between history and the present. It needs to be remarked though that genre-wise, Scott's text is far from being homogenous. Much more than classic novels by Defoe, Fielding and Richardson it replies on "extra-textual" elements, such as notes, commentaries, samples of folklore, i.e., something that Waverley shares with much of contemporary fiction. 
Scott's novel is published at the dawn of a period characterized by historicism. Yet, it needs to be stressed that the disturbing relationship between history and fiction (understood as any narrative of imaginary character) is nothing and was much discussed even in the preceding period. The connection between the early novel (mainly Defoe) and historical debates are treated, among others, by Robert Mayer in his History and the Early English Novel, Matters of Fact from Bacon to Defoe. Mayer quotes Michael McKeon's statement that the novel was "dialectically constituted by a debate between romance and history as well as between competing epistemological and ideological positions" (13). Mayer objects - quite reasonably - that such a concept of the novel cannot explain the close connection to discussions about the difference between history and fiction. Mayer goes on to follow this line of argument all the way to Renaissance thinkers (e.g., William Camden) and uses their example to show how vague and historically unfounded the sharp distinction between history and fiction was. The contours are vague for nearly two centuries and the main criterion is far from being an "objective" truth that can be supported by sources - rather the contrary, the first scholars examining actual historical sources are disparaged as mere "antiquaries", their work ridiculed as "musty" (Thomas Nashe) or as gathering "of some remnants of history which have casually escaped the shipwreck of time" (Francis Bacon) while the real history is the one that takes into account other aspects, be it utility (Bacon), national interest (Churchill and others who defended Geoffrey of Monmouth), readability or upholding the status quo in a particular community (the famous example being Richard Gough's The History of the Myddle). It is in this context, suggests Mayer, that we should read the early English fiction, such as Robinson Crusoe. Seen from the perspective of historical veracity, this novel is closer to the famous biographies such as those by Clarendon or Hutchinson. Veracity is guaranteed individually (when individuality is defined in Lockean terms as the identity of consciousness in time) in a performative way by pronouncing the "I": I was the direct witness of these events and in this way I narrate them to you. It is from individuality, individual consciousness and its uniqueness that the modern novel is born, as has been shown by Ian Watt. The novel, as characterized by Watt, however, has one more exceptional feature: it captures reality in its width of scope and variety, which - one may add - strengthens its claim to truth and veracity. "If the novel were realistic merely because it saw life from the seamy side, it would only be an inverted romance; but in fact it surely attempts to portray all the varieties of human experience, and not merely those suited to one particular literary perspective: the novel's realism does not 
reside in the kind of life it presents, but in the way it presents it" (11). Further Watt emphasizes the above mentioned "individual experience" - it is always unique, new and, the same as historical events, it differs from ready-made patterns or mythical structures and plots. This is the reason, says Watt, why the novel must be formless: "the poverty of the novel's formal conventions would seem to be the price it must pay for its realism" (13). The claim to truth of the Defoean "I" is based on a wider Puritan framework, in which speakers, narrating their own stories, open their souls and present their moral beings to readers $(75)$.

In the $18^{\text {th }}$ century, the Aristotelian perspective seems to return to the discussion about the relationship between historiography and literature. David Hume believes that historiography and epic poetry differ "not in kind but in degree" of the unity of actions; Hugh Blair thinks that it is the role of history to teach through facts and there is room for novels and romances in the discourse insofar as they can assume the pedagogical role. Adam Smith treats the problem similarly: history, he says, is characterized by its relation to the facts and its role is to teach, whereas novels and romances are products of poetic invention and their task is to entertain - that is why they are not seen as important by Smith. For discourse, they are irrelevant.

The attitude of the literati, however, is rather the contrary. They emphasize the importance of literature and build upon arguments raised by Aristotle or, later, by Philip Sidney. William Godwin sees "romance" as one of the kinds of history, because while a historian writes only about a single event and a single individual, writers gather their materials from many sources. Godwin goes even further: the author of "romance" is for him the author of true history:

The materials are abundant for the history of Alexander, Caesar, Cicero and Queen Elizabeth. Yet how widely do the best informed persons differ respecting them? Perhaps by all their character is misrepresented. The conjectures therefore respecting their motives in each particular transaction must be eternally fallacious. The writer of romance stands in this respect upon higher ground. He must be permitted, we should naturally suppose, to understand the character which is the creature of his own fancy. The writer of romance is to be considered as the writer of real history; while he who was formerly called historian, must be contended to step down into the place of his rival, with this disadvantage, that he is a romance writer, without the arduous, the enthusiastic and the sublime licence of imagination, that belong to that species of composition. 
What is of interest here is the genre terminology. Lukács, of course, calls Waverley a novel and sees it in a sharp contrast to romances. The relationship in Scott, however, is rather ambiguous. On one hand he makes a huge effort to persuade his readers that he is writing a novel, i.e., a piece of serious literature which is clearly defined in time and place (in this aspect, Waverley differs significantly from the Gothic novel, which is located just vaguely and set in some timeless Middle Ages) and he does not even attempt to hide his disdain for romances - in the preface, he defines his work against them and blames them for presenting a "debased" picture of history. The name "romance" is a priori excluded because it suggests frivolity, irrelevance. "Had I, for example, announced in my frontispiece, "Waverley, a Tale of other Days", must not every novel-reader have anticipated a castle scarce less than that of Udolpho, of which the eastern wing had been long uninhabited, and the keys either lost or consigned to the care of some aged butler or housekeeper, whose trembling steps, about the middle of the second volume, were doomed to guide the hero, or heroine, to the ruinous precincts?" (3). He then goes on to provide a description of his novel which is specifically differentiated from romance and, yet at the same time - which is a problem though - says that his main goal is to maintain the reader's interest (which brings it closer to romance) and warns the reader that he will not dwell so much on the historical detail; furthermore, readers are promised to be treated with a story of characters ("Considering the disadvantages inseparable from this part of my subject, I must be understood to have resolved to avoid them as much as possible, by throwing the force of my narrative upon the characters and passions of the actors; - those passions common to men in all stages of society, and which have alike agitated the human heart, whether it throbbed under the steel corset of the fifteenth century, the brocaded coat of the eighteenth, or the blue frock and white dimity waistcoat of the present day."), yet this is precisely what Scott is not going to provide: instead, we are given descriptions of mores and commentary. With some simplification it could perhaps be said that the "historical novel" in Scott's version becomes a hybrid, a combination of the despised romance and an essay or commentary on the habits and culture of the given time and environment. Similarly to Defoe who, in Robinson Crusoe, describes the everyday activities of a common man, Scott, too, declares that it is his interest to provide "more a description of men than manners" (Scott 4); yet, in his book, he does precisely the opposite, and the manners and "men" are reduced to mere types. 
In his book, Lukács emphasizes the importance of the choice of marginal characters - i.e., characters outside the main stream of events, not the front line heroes, generals, politicians but persons who do not seem important at first sight and attend the events from the sidelines. Such a choice, says Lukács, makes it possible to focus attention from an individual fate to more general forces and to capture the spirit of the age, or the emerging class consciousness. A few remarks should be made here: first, Lukács is right that in this particular case the relative unimportance of the main hero makes it possible for Scott to focus his attention on more general features of the time, but the question remains whether it is the class consciousness of the bourgeoisie, for whom the novel is written. Waverley was published in book form (anonymously) in 1814 but Scott says that he had worked on the text since 1805. In any case, the creation of the novel can be located to a period when the nationalistic tension, which is the main topic of the novel, was long gone, forgotten and - above all - the Jacobite rebellion was no longer a threat for the establishment. It should be added that the novel was immensely successful: the first edition was published on July 7, 1814, a thousand copies sold in just two days and three more editions were published by November. It is evident that Waverley is written neither for the Highlanders nor for revolutionary romantics. It is aimed at educated readers from the cities and for English readers. The Jacobite rebellion - and the surrounding folklore - is described as something "romantic", i.e., "not serious", "frivolous". It is no accident that the novel was written at the time when the revolutionary enthusiasm of the first generation of romantics was fading away. Radical enthusiasm, enveloped in the attractive folklore of the wild and proud Highlands, portrayed as one of the follies of youth, must have appealed to many a reader since it gave them an opportunity to shape their own past or justify it. Waverley is not a Bildungsroman because the main hero does not embark on any journey, spiritual or other; rather, it is a well calculated shot at the reader's conscience, giving them what they want to hear.

To satisfy the reader's thirst for a romantic setting, Scott does not hesitate to use anachronisms: including habits described which are often parts of "invented traditions", as analyzed by Hobsbawm and Ranger. These traditions were invented for the same purpose for which Scott writes his novel: to entertain, enchant and to function as a kind of set-piece for the "romantic" atmosphere. When Waverley arrives in Scotland, he is spellbound, the "country around was at once fertile and romantic" (Scott 185). This is an anachronism. 
If we take Daniel Defoe's Tour as reference we will see the huge difference in sensibility towards the landscape. While Scott's Waverley is much influenced by the Romantic movement, including the change of perspective on barren landscape, we will find nothing of that sort in Defoe who is writing his travelogue shortly before the events described in Waverley. There is no room for an aesthetics of sublime in Defoe, the perception of landscape is utilitarian, there is nothing in it which was later brought in by the poetry of Wordsworth or the influence of paintings by Claude. For Defoe, the country in the north, is hideous. Waverley, on the contrary, looks at it from an altogether different perspective - anachronistically, as a tourist who has read Wordsworth. It can even be said that this concept of landscape is identified with Waverley's youthful reading. It is a landscape of dreaming and Romantic poetry which and this is remarkable - is seen by Scott as an entertainment, something which is not to be taken seriously.

Romantic poetry becomes one of the follies of youth and in the novel serves to justify Waverley's "mistake" and his infatuation with the radical ideas of the Jacobites. Right at the beginning of the book, when Edward's education is being described, the author seems to suggest that the lack of discipline is to blame for any subsequent faults. Young Edward Waverley was given the basics of a rigorous classical education but other than that he could read what he wanted and this is seen as a major mistake. He enjoyed reading as "amusement", his teachers were too "indulgent", which took its toll on him. Reading and "ardent" love of literature set a spark to Edward's imagination which made the problem only worse. This random, undisciplined education is very close to the "Scottish education", represented by Major Bradwardine - his education being described as rather "diffuse" than "accurate".

Structurally, the novel is built on polarities which are diachronic: the former, however, is not refused directly, but only shifted - in a patronizing way - to the past as the folly of youth. Plainly speaking, Edward Waverley goes through no development - and in this he differs very much from the heroes of the traditional Bildungsroman or Defoe's Robinson Crusoe or Moll Flanders: he just replaces a set of attitudes to life by another which is more beneficial for him at the moment.

But to return to the topic of history and its treatment in Waverley. Scott rejects romance as something frivolous, similar to the romantic poetry which led Edward astray. Romances are also rejected in order to claim the status of the novel, a kind of narrative which is more generally accepted. Contrary to what György Lukács says, Walter Scott does not write a historical novel - 
rather, he provides the reader with a strange mix of history and romance with the purpose of sterilizing history and presenting it as something amusing and harmless.

This particular mixture of history and romance - rather than a fully-fledged novel - is something that makes Scott very modern. In the recent historical turn in fiction, similar strategies are used for various purposes: whether to sanitize history, as Scott does, or to undermine the established interpretation of it, as many practitioners of historical fiction do today. However, it would be wrong, I want to argue, to see historical fiction as something that builds upon the serious and respectable fathers of the novel and to disregard all the preceding, sometimes marginalized genres such as romance or fantasy.

\section{Works Cited}

Byatt, A. S. On Histories and Stories, Selected Essays. London: Chatto \& Windus, 200o. Print.

de Groot, Jerome. The Historical Novel. London: Routledge, 2010. Print. Elias, Amy J. Sublime Desire. Baltimore and London: The John Hopkins University Press, 2001. Print.

Godwin, William. "Of History and Romance." wrere.english.upenn.edu. University of Pennsylvania, n.d. Web. 12 March 2014.

Higdon, David Leon. Shadows of the Past in Contemporary British Fiction. London: Macmillan, 1984. Print.

Hobsbawm Eric and Ranger Terence, eds. The Invention of Tradition. Cambridge: Cambridge University Press, 1983. Print.

Keen, Suzanne. "The Historical Turn in British Fiction." James F. English, ed. A Concise Companion to Contemporary British Fiction. Oxford: Blackwell, 2006. Print.

Lukács, Georg. The Historical Novel. Harmondsworth: Penguin, 1981. Print. Mayer, Robert. History and the Early English Novel, Matters of Fact from Bacon to Defoe. Cambridge: Cambridge University Press, 1997. Print.

Scott, Walter, Waverley. Oxford: Oxford Unversity Press, 2008. Print.

Watt, Ian. The Rise of the Novel. London: Pimlico, 2000. Print. 